\title{
Syntheses of 1,1-Organo-substituted Silole Derivatives. 1,1-Ethylboration, 1,1-Vinylboration and Protodeborylation
}

\author{
Ezzat Khan $^{\mathrm{a}, \mathrm{b}}$, Stefan Bayer ${ }^{\mathrm{a}}$, and Bernd Wrackmeyer ${ }^{\mathrm{a}}$ \\ a Anorganische Chemie II, Universität Bayreuth, 95440 Bayreuth, Germany \\ b Department of Chemistry University of Malakand, Chakdara, Dir(Lower), N. W. F. P., Pakistan \\ Reprint requests to Prof. Dr. B. Wrackmeyer. E-mail: b.wrack@uni-bayreuth.de
}

Z. Naturforsch. 2009, 64b, 995 - 1002; received June 9, 2009

1,1-Organoboration of dialkyn-1-ylsilanes using triethylborane, $\mathrm{BEt}_{3}$, and 9-ethyl-9-borabicyclo [3.3.1]nonane, Et-9-BBN, was carried out at elevated temperatures, $100-120{ }^{\circ} \mathrm{C}$. These reactions afforded selectively silole derivatives bearing the dialkylboryl group in 3-position. The siloles are formed via intermolecular 1,1-alkylboration, followed by intramolecular 1,1-vinylboration. Two examples of boryl-substituted siloles were treated with an excess of acetic acid at ambient temperature to afford the respective protodeborylated compounds. All new compounds were characterized in solution by multinuclear magnetic resonance spectroscopy $\left({ }^{1} \mathrm{H},{ }^{13} \mathrm{C},{ }^{11} \mathrm{~B}\right.$ and $\left.{ }^{29} \mathrm{Si} \mathrm{NMR}\right)$.

Key words: Alkynylsilanes, Siloles, Organoboration, Triethylborane, NMR

\section{Introduction}

Dialkyn-1-ylsilanes [1-3] and triorganoboranes [4-6] have numerous applications in chemistry. By combining these useful classes of compounds, it proved possible to develop a versatile synthesis of siloles [7-9] via organoboration reactions [10,11]. Recently, it has been shown that siloles can also be obtained by using tris(pentafluorophenyl)borane, $B\left(C_{6} F_{5}\right)_{3}$, as the organoborating reagent [12]. Since siloles have become increasingly important owing to their peculiar photophysical properties [13-15], further efforts were made to use organoboration aiming for a greater variety of substituents in all five ring positions. So far, siloles of type $\mathbf{A}$ were obtained in high yield from dialkyn-1-yldimethylsilanes 1 (Scheme 1a) [10a], and similarly siloles $\mathbf{C}$ were prepared from $\mathbf{B}$, however under less harsh conditions (Scheme 1b) [10b].

In the present report, we describe the synthesis of siloles analogous to $\mathbf{A}$ by varying the organyl groups linked to silicon and also by using 9-ethyl-9borabicyclo[3,3,1]nonane (Et-9-BBN) instead of triethylborane, $\mathrm{BEt}_{3}$, as an organoborating reagent.

\section{Results and Discussion}

The dialkyn-1-ylsilanes $\mathbf{2}-\mathbf{5}$ were prepared in the usual way by the reactions of the respective alkynyllithium reagents with diorganosilicon dichlorides [16]. NMR spectroscopic data of the new alkyn-1-ylsilanes (a)<smiles>[R][SiH]([R])([R])C</smiles>

1<smiles>[R]C1=C([R])[Si](=O)C([R])=C1[R]</smiles>

A (b)<smiles>[R]C1=C([As])[SiH]1C</smiles>

B

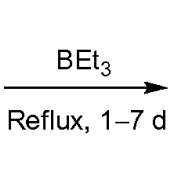

$\mathrm{R}=\mathrm{Me}, \mathrm{Bu},{ }^{\mathrm{t}} \mathrm{Bu},{ }^{i} \mathrm{Pent}, \mathrm{Ph}, \mathrm{SiMe}_{3}$
Scheme 1. 1,1-Dimethylsilole derivatives obtained via 1,1organoboration as described in ref. [10].

$(\mathbf{4 a}-\mathbf{d})$ are listed in Table 1, and for the other precursor alkynes, such data will be described elsewhere [17].

The reaction of various dialkyn-1-yldiorganosilanes 2-5 with an excess of $\mathrm{BEt}_{3}$ is shown in Scheme 2. The yields are essentially quantitative after prolonged periods of heating. The products are the siloles $\mathbf{6}-$ 8 which were obtained as air-sensitive oily liquids or waxy solids. Their purity and structure in solution follow from consistent sets of characteristic NMR data (Table 2). This is illustrated by the ${ }^{13} \mathrm{C}$ NMR spectra in Fig. 1 which also shows the clean formation of the corresponding protodeborylatetd silole (vide infra).

In the case of $\mathbf{5}$, the reaction afforded mainly $(\approx 80 \%)$ the silole 9 along with a small amount 
Table $1 .{ }^{13} \mathrm{C}$ and ${ }^{29} \mathrm{Si} \mathrm{NMR}$ data ${ }^{\mathrm{a}}$ for the silane derivatives $\mathbf{4 a}-\mathbf{d}$.

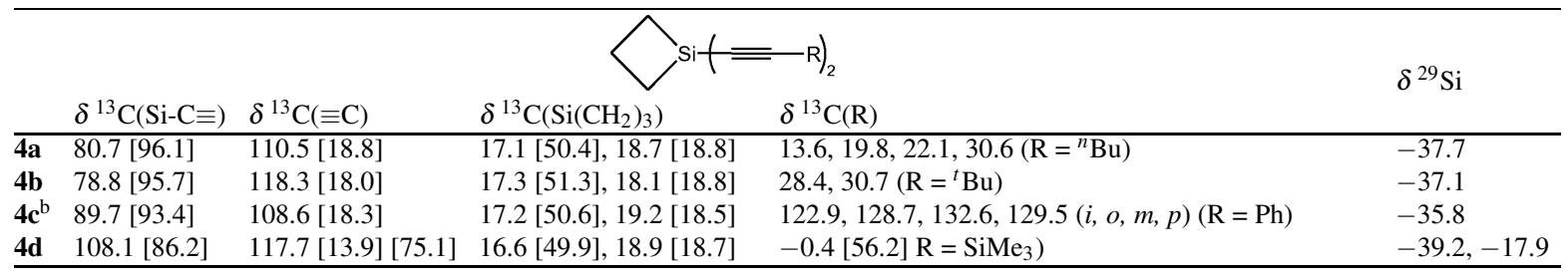

${ }^{\text {a }}$ Measured in $\mathrm{C}_{6} \mathrm{D}_{6}$ at $23 \pm 1{ }^{\circ} \mathrm{C}$, coupling constants ${ }^{1} \mathrm{~J}\left({ }^{29} \mathrm{Si},{ }^{13} \mathrm{C}\right)$ and ${ }^{2} \mathrm{~J}\left({ }^{29} \mathrm{Si},{ }^{13} \mathrm{C}\right)[\mathrm{Hz}]$ are given in brackets; ${ }^{\mathrm{b}}$ measured in $\mathrm{CDCl}_{3}$.

Table $2 .{ }^{11} \mathrm{~B},{ }^{13} \mathrm{C}$ and ${ }^{29} \mathrm{Si} \mathrm{NMR}$ data ${ }^{\mathrm{a}}$ for the siloles $\mathbf{6}-\mathbf{1 1}$ and $\mathbf{A}[10 \mathrm{a}]$ for comparison.

\begin{tabular}{|c|c|c|c|c|c|c|}
\hline & \multirow[b]{2}{*}{$\mathrm{C}-2$} & \multicolumn{2}{|c|}{$\delta^{13} \mathrm{C}$} & & \multirow[t]{2}{*}{$\delta^{29} \mathrm{Si}$} & \multirow[t]{2}{*}{$\delta^{11} \mathrm{~B}$} \\
\hline & & $\mathrm{C}-3$ & C-4 & C-5 & & \\
\hline$\overline{\mathrm{A}(\mathrm{R}=\mathrm{Bu})}$ & $140.8[64.1]$ & 165.8 (br) & $153.6[10.7]$ & $136.2[68.2]$ & 5.2 & 86.7 \\
\hline $\mathbf{6 a}^{\mathrm{b}}(\mathrm{Bu})$ & 140.9 [64.5] & 168.1 (br) & $155.9[11.2]$ & 136.5 [69.9] & -0.4 & 88.1 \\
\hline $6 c^{c}(P h)$ & 140.9 [58.2] & 170.4 (br) & $157.9[10.1]$ & $134.7[65.6]$ & 1.9 & 87.0 \\
\hline $7 \mathbf{a}^{\mathrm{d}}(\mathrm{Bu})$ & $140.0[65.9]$ & 169.6 (br) & $157.6[11.3]$ & $134.8[67.5]$ & -4.6 & 86.5 \\
\hline $\mathbf{8} \mathbf{a}^{\mathrm{e}}(\mathrm{Bu})$ & $137.1[59.0]$ & $167.4(\mathrm{br})$ & $155.5[10.4]$ & $132.8[63.1]$ & 18.4 & 88.3 \\
\hline $\mathbf{8} \mathbf{b}^{\mathrm{f}}\left({ }^{t} \mathrm{Bu}\right)$ & $147.7[59.7]$ & 164.4 (br) & $154.5[11.6]$ & 141.1 [n. d.] & 22.7 & 89.0 \\
\hline $8 c^{\mathrm{g}}(\mathrm{Ph})$ & 142.2 & 169.3 (br) & $157.7[9.5]$ & 141.0 & 19.9 & 89.2 \\
\hline $\mathbf{8} \mathbf{d}^{\mathrm{h}}\left(\mathrm{SiMe}_{3}\right)$ & $142.1[38.6,63.6]$ & 185.1 (br) & $171.7[8.1,11.1]$ & $134.0[43.0,62.2]$ & 40.2 & 88.5 \\
\hline $9^{i}$ & $133.9[62.9,51.5]$ & 176.1 (br) & $171.8[5.1]$ & $135.8[60.5]$ & $17.5,-11.4$ & 87.6 \\
\hline $11 \mathrm{c}^{\mathrm{j}}(\mathrm{Ph})$ & $149.7[62.8]$ & 169.7 (br) & $165.4[8.8]$ & $137.6[66.3]$ & 6.9 & 87.8 \\
\hline
\end{tabular}

${ }^{\text {a }}$ Measured in $\mathrm{C}_{6} \mathrm{D}_{6}$ at $296 \pm 1 \mathrm{~K}$; coupling constants ${ }^{1} \mathrm{~J}\left({ }^{29} \mathrm{Si},{ }^{13} \mathrm{C}\right)$ and ${ }^{2} J\left({ }^{29} \mathrm{Si},{ }^{13} \mathrm{C}\right)[\mathrm{Hz}]$ are given in brackets; br denotes broad ${ }^{13} \mathrm{C}$ NMR signal owing to partially relaxed ${ }^{13} \mathrm{C}-{ }^{11} \mathrm{~B}$ spin-spin coupling [25]; $\quad{ }^{\mathrm{b}}$ other ${ }^{13} \mathrm{C}$ NMR data: $\left.\delta\left[\mathrm{J}^{29} \mathrm{Si},{ }^{13} \mathrm{C}\right)\right]=-5.5[49.4, \mathrm{Si}-\mathrm{Me}], 24.7,14.2$ (Et), 22.8 (br), $9.4\left(\mathrm{BEt}_{2}\right), 34.0,33.4,32.7,28.8,23.3,23.3,14.1,14.2(\mathrm{Bu}), 136.3$ [62.9], 134.5, 128.3, $129.5(i, o, m, p, \mathrm{Si}-\mathrm{Ph}) ; \quad \mathrm{c}$ other ${ }^{13} \mathrm{C}$ NMR data: $\delta\left[J\left({ }^{29} \mathrm{Si},{ }^{13} \mathrm{C}\right)\right]=-6.4[51.4, \mathrm{Si}-\mathrm{Me}], 24.8,14.5(\mathrm{Et}), 22.3(\mathrm{br}), 9.9\left(\mathrm{BEt}_{2}\right), 140.1[65.5], 134.8,128.7,130.0(i, o, m, p$, $\mathrm{Si}-\mathrm{Ph}), 145.0,141.9,128.7,128.6,128.2,127.7,125.9,126.4(i, i, o, o, m, m, p, p, \mathrm{Ph})$; ${ }^{\mathrm{d}}$ other ${ }^{13} \mathrm{C} \mathrm{NMR}$ data: $\delta\left[J\left({ }^{29} \mathrm{Si},{ }^{13} \mathrm{C}\right)\right]=34.0$, 33.4, 33.2, 29.1, 23.3, 14.2, 14.1 (Bu), 24.9, $14.0(\mathrm{Et}), 22.9 / \mathrm{br}), 9.5\left(\mathrm{BEt}_{2}\right), 135.8$ [62.1], 135.9, 128.4, 129.8 (i,o, $\left.m, p, \mathrm{SiPh}_{2}\right)$; e other ${ }^{13} \mathrm{C}$ NMR data: $\left.\delta\left[\mathrm{J}^{(29} \mathrm{Si},{ }^{13} \mathrm{C}\right)\right]=14.0,32.6(\mathrm{Et}), 22.8(\mathrm{br}), 9.2\left(\mathrm{BEt}_{2}\right), 14.8,23.6,28.4,33.7,34.0(\mathrm{Bu}), 14.3,19.1\left(\left(\mathrm{CH}_{2}\right)_{3}\right) ; \quad \mathrm{f}$ other ${ }^{13} \mathrm{C}$ NMR data: $\delta\left[J\left({ }^{29} \mathrm{Si}^{13}{ }^{13} \mathrm{C}\right)\right]=14.9,31.7(\mathrm{Et}), 22.5(\mathrm{br}), 10.2\left(\mathrm{BEt}_{2}\right), 32.9,30.8\left({ }^{t} \mathrm{Bu}\right), 16.0$ [39.2], 18.6 [15.5] $\left(\left(\mathrm{CH}_{2}\right)_{3}\right) ; \quad \mathrm{g}$ other ${ }^{13} \mathrm{C}$ NMR data: $\left.\delta\left[\mathrm{J}^{29}{ }^{\mathrm{Si}},{ }^{13} \mathrm{C}\right)\right]=13.9,31.2(\mathrm{Et}), 22.0(\mathrm{br}), 9.4\left(\mathrm{BEt}_{2}\right), 128.4,128.8,126.9,129.3(i, o, m, p, \mathrm{Ph}), 13.9[40.3], 19.3[16.4$ $\left.\left(\mathrm{CH}_{2}\right)_{3}\right) ; \quad{ }^{\mathrm{h}}$ other ${ }^{13} \mathrm{C}$ NMR data: $\delta\left[J\left({ }^{29} \mathrm{Si},{ }^{13} \mathrm{C}\right)\right]=15.3,30.0(\mathrm{Et}), 23.0(\mathrm{br}), 9.4\left(\mathrm{BEt}_{2}\right), 1.6$ [51.3, $\left.\mathrm{SiMe}_{3}\right], 1.7$ [51.6, $\left.\mathrm{SiMe}_{3}\right], 14.3$ [38.8], $\left.19.0[15.5]\left(\mathrm{CH}_{2}\right)_{3}\right) ; \quad$ i the silole 9 is numbered in this way for consistency of the data; other ${ }^{13} \mathrm{C}$ NMR data: $\delta\left[J\left({ }^{29} \mathrm{Si},{ }^{13} \mathrm{C}\right)\right]=-3.3[48.8$, $\left.\mathrm{SiMe}_{3}\right], 1.5\left[51.3, \mathrm{SiMe}_{2}\right], 9.2,21.0(\mathrm{br})\left(\mathrm{BEt}_{2}\right), 14.4,30.4(\mathrm{Et}) ; \quad{ }^{\mathrm{j}}$ other ${ }^{13} \mathrm{C} \mathrm{NMR}$ data: $\delta\left[{ }^{2}\left({ }^{29} \mathrm{Si},{ }^{13} \mathrm{C}\right)\right]=-3.7\left[49.3, \mathrm{SiMe}_{2}\right], 11.2,22.7$ (br), 21.7, 30.6, 34.8, 35.0 (br) (BEt, $\left.\mathrm{BC}_{8} \mathrm{H}_{14}\right), 134.3[6.9, i], 141.6[5.8, i], 128.7,128.6,128.0,127.8,126.6,126.7\left(2,5-\mathrm{Ph}_{2}\right)$.<smiles>[R]C#[Si]([R2])([R])C#[R]</smiles>

2: $\mathrm{R}^{1}=\mathrm{Me} ; \mathrm{R}^{2}=\mathrm{Ph} ; \mathrm{R}=\mathrm{Bu}(\mathrm{a}), \mathrm{Ph}(\mathbf{c})$

3: $\mathrm{R}^{1}=\mathrm{R}^{2}=\mathrm{Ph} ; \mathrm{R}=\mathrm{Bu}(\mathrm{a})$

4: $\mathrm{R}^{1} / \mathrm{R}^{2}=\left(\mathrm{CH}_{2}\right)_{3}$;

$\mathrm{R}=\mathrm{Bu}(\mathrm{a}),{ }^{t} \mathrm{Bu}(\mathrm{b}), \mathrm{Ph}(\mathrm{c}), \mathrm{SiMe}_{3}(\mathrm{~d})$<smiles>CC#C[Si](C)(C)C</smiles>

5

5

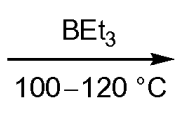

$00-120^{\circ} \mathrm{C}$<smiles>[R7]C1=C([R])[Si]([R])([R])C([R])=C1[R]</smiles>

$\mathrm{R}^{1}=\mathrm{Me} ; \mathrm{R}^{2}=\mathrm{Ph} ; \mathbf{6 a}, \mathrm{c}$

$\mathrm{R}^{1}=\mathrm{R}^{2}=\mathrm{Ph} ; \mathbf{7 a}$

$\mathrm{R}^{1 / \mathrm{R}^{2}}=\left(\mathrm{CH}_{2}\right)_{3} ; \mathbf{8 a}, \mathbf{b}, \mathbf{c}, \mathbf{d}$

$(<5 \%)$ of the silole $\mathbf{9}^{\prime}$, which results from intermolec-

ular 1,1-ethylboration of the $\mathrm{Si}-\mathrm{C} \equiv \mathrm{CH}$ unit in the first

step. In contrast, 9 is formed by intermolecular 1,1-ethylboration of the more reactive $\mathrm{Si}-\mathrm{C} \equiv \mathrm{C}-\mathrm{SiMe}_{3}$ unit

Scheme 2. 1,1-Ethylboration of the dialkyn-1-ylsilanes 2-5 using $\mathrm{BEt}_{3}$. 

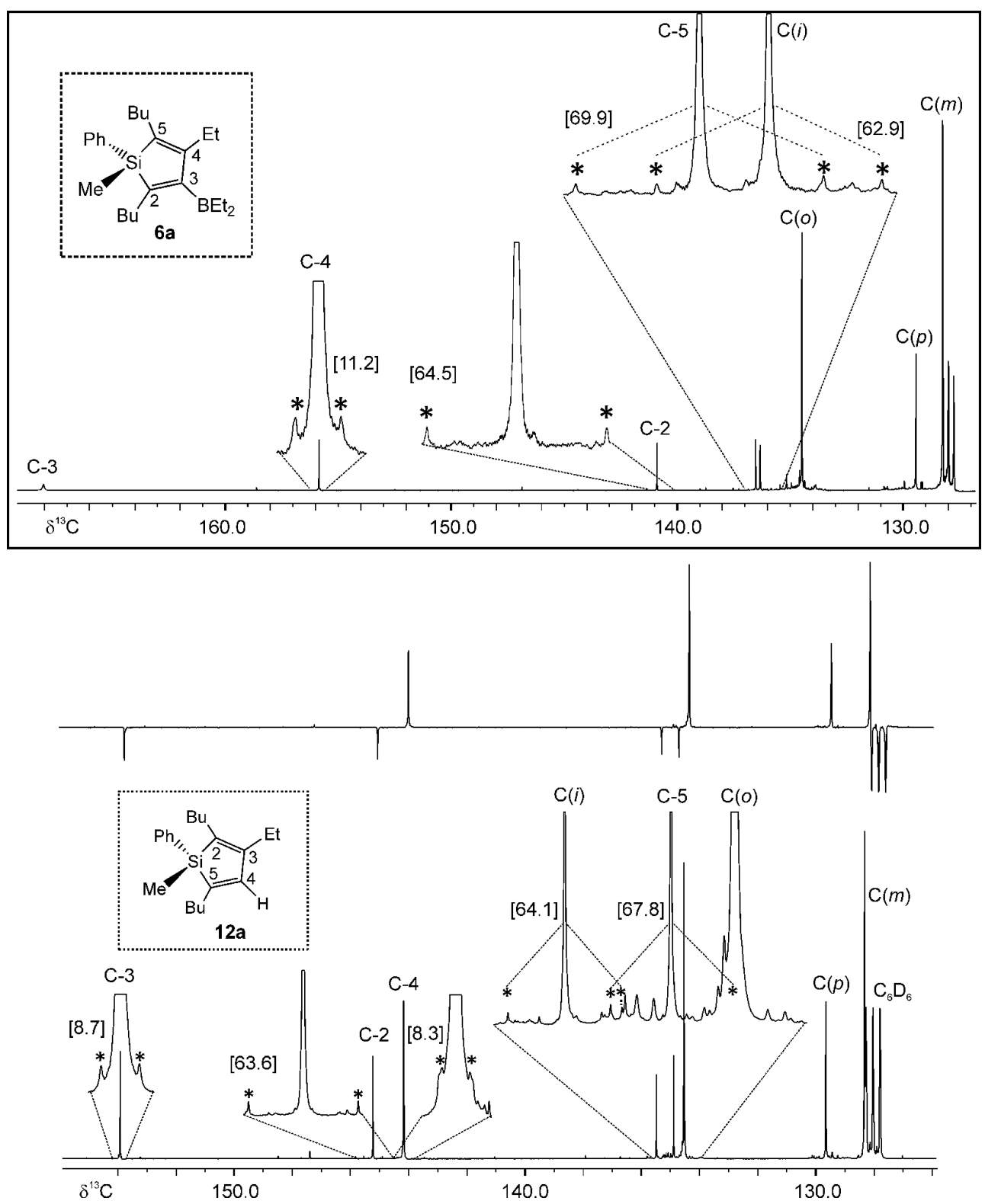

Fig. 1. Part of the $100.5 \mathrm{MHz}{ }^{13} \mathrm{C}\left\{{ }^{1} \mathrm{H}\right\}$ NMR spectrum of the 3-diethylborylsilole derivative $\mathbf{6 a}$ (upper inset). The same spectral region is shown for the protodeborylated silole 12a (middle trace: J-modulated experiment in the middle and normal ${ }^{13} \mathrm{C}\left\{{ }^{1} \mathrm{H}\right\}$ NMR in the lower trace). ${ }^{29} \mathrm{Si}$ satellites (marked by asterisks in expansions) indicate coupling constants ${ }^{1} J\left({ }^{29} \mathrm{Si},{ }^{13} \mathrm{C}\right)$ and ${ }^{2} J\left({ }^{29} \mathrm{Si},{ }^{13} \mathrm{C}\right)$ (values are given in brackets; see also Tables 2 and 3 ).
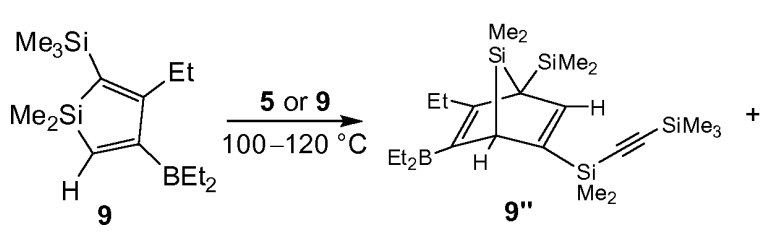

9"

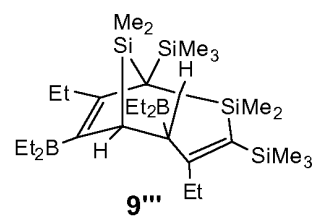

Scheme 3. $[4+2]$ Cycloaddition reactions of the silole 9 . 


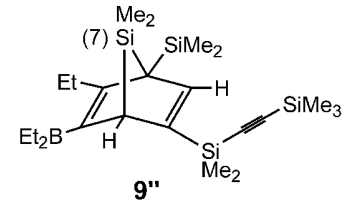

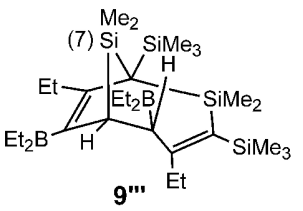
9"'<smiles>CCc1c([As])[se]c([As])c1CC</smiles><smiles></smiles>

9

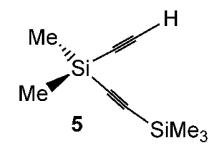

Fig. 2. $59.6 \mathrm{MHz}{ }^{29} \mathrm{Si}\left\{{ }^{1} \mathrm{H}\right\}$ NMR spectrum (INEPT, refocused [23]) of the reaction mixture after $2 \mathrm{~d}$ of heating 5 in $\mathrm{BEt}_{3}$ as a solvent at $110{ }^{\circ} \mathrm{C}$. The mixture contains $5,9,9^{\prime}, 9^{\prime \prime}$, and $\mathbf{9}^{\prime \prime \prime}$.

in the first step, followed by fast intramolecular 1,1vinylboration of the $\mathrm{Si}-\mathrm{C} \equiv \mathrm{C}-\mathrm{H}$ unit. Under the reaction conditions, the silole derivative 9 reacts further (Scheme 3) via [4+2]cycloadditions, either with the starting silane $\mathbf{5}$ or with one of its kind to afford the 7-silanorbornadiene $9^{\prime \prime}(\approx 5 \%)$ and a tricyclic 7silanorbornene derivative $9^{\prime \prime \prime}$, respectively. The NMR spectroscopic data, in particular those obtained from ${ }^{29} \mathrm{Si}$ NMR spectra, are very helpful (Fig. 2) in the identification of such products. For compound $\mathbf{9}^{\prime \prime}$, all the ${ }^{29} \mathrm{Si}$ chemical shifts $\left[\delta^{29} \mathrm{Si}=79.0\left(7-\mathrm{SiMe}_{2}\right),-3.9\right.$ $\left.\left(\mathrm{SiMe}_{3}\right),-19.7\left(\mathrm{C} \equiv \mathrm{C}-\mathrm{SiMe}_{3}\right),-28.3 \mathrm{ppm}\left(\mathrm{SiMe}_{2}\right)\right]$ and relevant ${ }^{1} \mathrm{H}$ NMR signals $\left[e . g . \delta^{1} \mathrm{H}(=\mathrm{CH})=\right.$ $\left.6.92 \mathrm{ppm}\left(\mathrm{d}, J\left({ }^{1} \mathrm{H},{ }^{1} \mathrm{H}\right)=1.5 \mathrm{~Hz}\right)\right]$ can be found in the expected regions [18]. Numerous additional ${ }^{29} \mathrm{Si}$ NMR signals of low intensities grow with time, and from these it appears that 9 undergoes [4+2]cycloadditions with one of its kind to give $\mathbf{9}^{\prime \prime \prime}$, for which at least the ${ }^{29} \mathrm{Si}$ NMR signal of the 7-silanorbornene unit $\left(\delta^{29} \mathrm{Si}=\right.$ 41.5) [18]) as well as the ${ }^{29} \mathrm{Si} \mathrm{NMR}$ signal of the $\mathrm{SiMe}_{2}$ group as part of the silacyclopent-2-ene ring $\left(\delta^{29} \mathrm{Si}=\right.$ 23.2) are typical. Other spurious signals may arise by 1,1-ethylboration of the $\mathrm{Si}-\mathrm{C} \equiv \mathrm{C}-\mathrm{H}$ unit in $\mathbf{9}^{\prime \prime}$ or by the - likely - formation of other isomers in the [4+2] cycloaddition reactions. Owing to the low concentration of the compounds $9^{\prime \prime}, 9^{\prime \prime \prime}$ and others, we did not attempt to assign ${ }^{1} \mathrm{H}$ and ${ }^{13} \mathrm{C}$ NMR signals to these compounds i.e., $9^{\prime \prime}$ and $9^{\prime \prime \prime}$.

In the cases of the 1,1-dialkyn-1-ylsilacyclobutane derivatives $\mathbf{4 b}$ and $\mathbf{4 c}$, the reactions with $\mathrm{BEt}_{3}$ lead to the siloles $\mathbf{8 b}$, c along with side products $\mathbf{1 0 b}, \mathbf{c}$ (Scheme 4), for which the stereochemistry does not
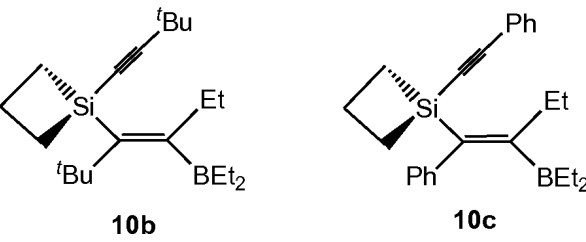

Scheme 4. Side products from the 1,1-organoboration of $\mathbf{4 b}$, c, unsuitable for further rearrangements to afford the corresponding silole derivatives.

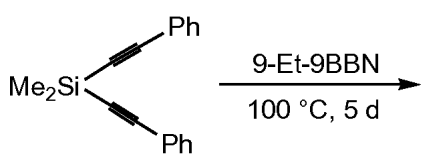

$1 c$

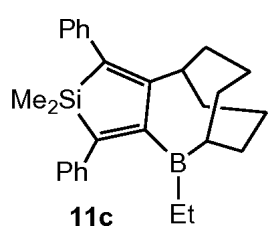

Scheme 5. 9-Ethyl-9-borabicyclo[3.3.1]nonane, 9-Et-9$\mathrm{BBN}$, is used as an organoborating reagent to afford the polycyclic silole 11c.

allow for a rearrangement towards ring closure. The corresponding $Z$-isomers were not detected.

The rate-determining step of the silole formation via 1,1-organoboration is the intermolecular 1,1-ethylboration in all cases, followed by the fast intramolecular 1,1-vinylboration, if the stereochemistry of the alkenyl-alkyn-1-ylsilane is favorable. In our previous work it was found that $\mathrm{BEt}_{3}$ can react with certain alkyn-1-ylsilanes as a 1,2-hydroborating reagent $[19,20]$. This was not observed in the present work.

The harsh reaction condition required for the 1,1organoboration of dialkyn-1-ylsilanes restrict these reactions to thermally stable triorganoboranes. This 
Table $3 .{ }^{13} \mathrm{C}$ and ${ }^{29} \mathrm{Si}$ NMR data ${ }^{\mathrm{a}}$ for the siloles 12a, $\mathbf{c}$.

\begin{tabular}{llll}
\hline & 12a & 12c \\
\hline & $\delta^{13} \mathrm{C}(\mathrm{C}-2)$ & $145.2[63.6]$ & $143.8[64.2]$ \\
$\delta^{13} \mathrm{C}(\mathrm{C}-3)$ & $144.2[8.3]$ & $143.3[7.2]$ \\
$\delta^{13} \mathrm{C}(\mathrm{C}-4)$ & $153.9[8.7]$ & $155.3[7.9]$ \\
$\delta^{13} \mathrm{C}(\mathrm{C}-5)$ & $134.9[67.8]$ & $138.1[67.4]$ \\
$\delta^{13} \mathrm{C}(\mathrm{Et})$ & $13.7,23.8$ & $13.8,24.8$ \\
$\mathrm{R}=\mathrm{Bu}(\mathbf{a})$ & $\delta^{13} \mathrm{C}(\mathrm{Si}-\mathrm{Me})$ & $-6.2[49.7]$ & $-6.2[51.9]$ \\
$\mathrm{R}=\mathrm{Ph}(\mathbf{c})$ & $\delta^{13} \mathrm{C}(\mathrm{Si}-\mathrm{Ph})$ & $135.5[64.1], 134.5,128.3,129.6(i, o, m, p)$ & $140.4[5.8], 138.9[5.9], 134.2[66.5], 134.8,130.1$, \\
& $\delta^{13} \mathrm{C}(\mathrm{R})$ & $14.1,14.1,22.9,23.2,28.7,32.3,32.8,33.3$ & $129.0,128.7,128.6,128.3,127.3,126.9,126.1^{\mathrm{b}}$ \\
& $\delta^{29} \mathrm{Si}$ & -1.6 & 1.0 \\
\hline
\end{tabular}

${ }^{\text {a }}$ Measured in $\mathrm{C}_{6} \mathrm{D}_{6}$ at $23 \pm 1{ }^{\circ} \mathrm{C}$, coupling constants ${ }^{1} J\left({ }^{29} \mathrm{Si},{ }^{13} \mathrm{C}\right)$ and ${ }^{2} J\left({ }^{29} \mathrm{Si},{ }^{13} \mathrm{C}\right)[\mathrm{Hz}]$ are given in brackets; ${ }^{\mathrm{b}} \mathrm{Ph}$ carbons without assignment.
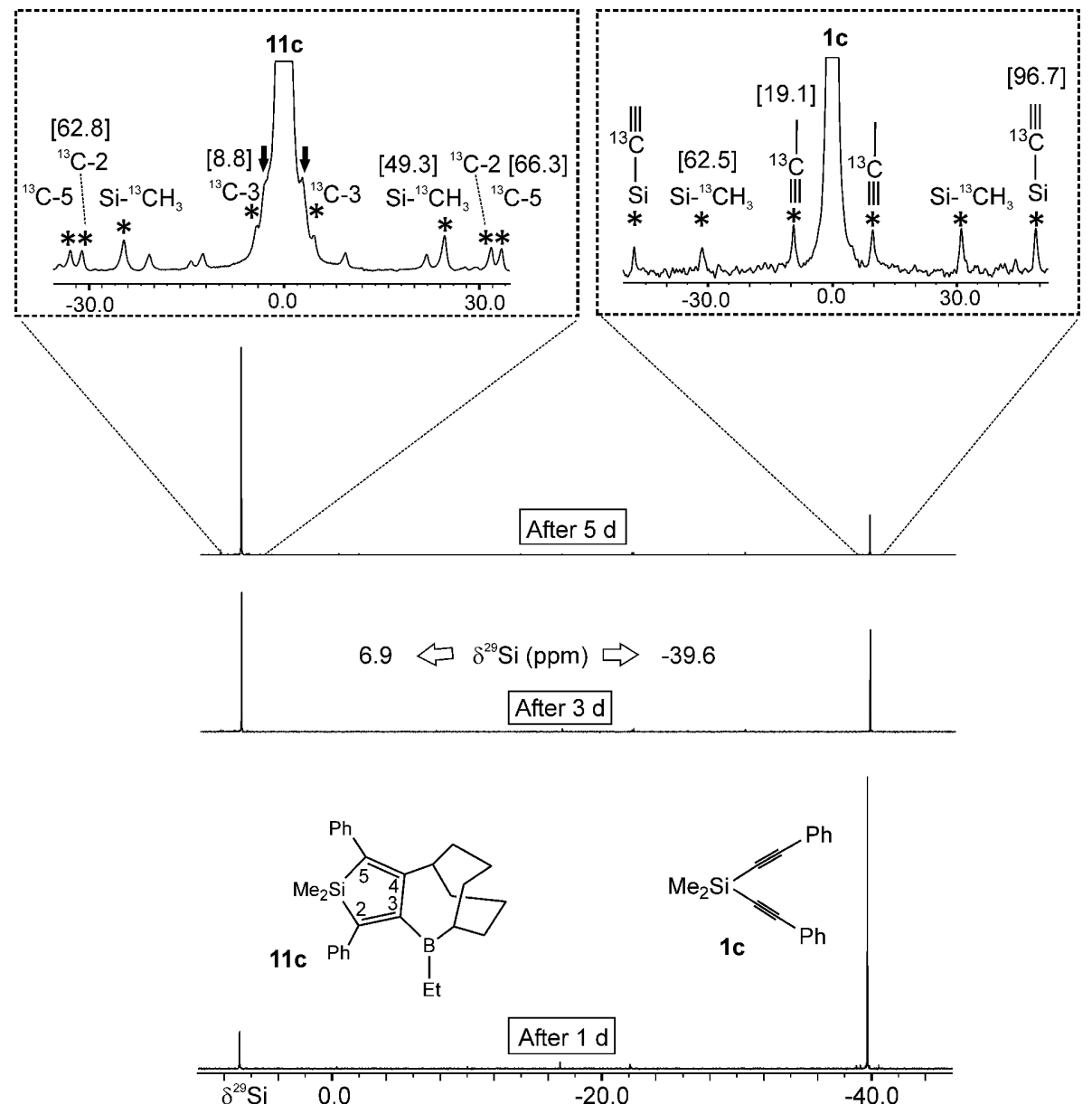

condition is fulfilled by 9-ethyl-9- borabicyclo[3.3.1] nonane, Et-9-BBN, as shown in Scheme 5. The reaction proceeds by twofold ring expansion of the bicyclic system to give selectively the polycyclic silole 11c. During the course of the reaction no intermediates or other products were observed (Fig. 3).
Fig. 3. Monitoring of the reaction of di(phenylethynyl) dimethylsilane 1c with Et-9-BBN by ${ }^{29}$ Si NMR spectroscopy (INEPT, refocused [23]). The ${ }^{29} \mathrm{Si}$ NMR signal for 1c disappeared after $7 \mathrm{~d}$. Expansions are shown for the two signals corresponding to $\mathbf{1 c}$ and the silole $11 \mathrm{c}$, and ${ }^{13} \mathrm{C}$ satellite signals corresponding to coupling constants ${ }^{1} J\left({ }^{29} \mathrm{Si},{ }^{13} \mathrm{C}\right)$ and ${ }^{2} J\left({ }^{29} \mathrm{Si},{ }^{13} \mathrm{C}\right)$ are marked by asterisks and arrows, respectively. All values (Table 2) are also evident from the respective ${ }^{13} \mathrm{C} \quad \mathrm{NMR}$ spectra.

As an example for the protodeborylation of the siloles reported here, the siloles $\mathbf{6 a}, \mathbf{c}$ were treated with an excess of acetic acid (Scheme 6). These reactions afforded smoothly in essentially quantitative yield the siloles 12a, c (see NMR data in Table 3, and also Fig. 1 for the ${ }^{13} \mathrm{C}\left\{{ }^{1} \mathrm{H}\right\}$ NMR spectrum of 12a), along with 


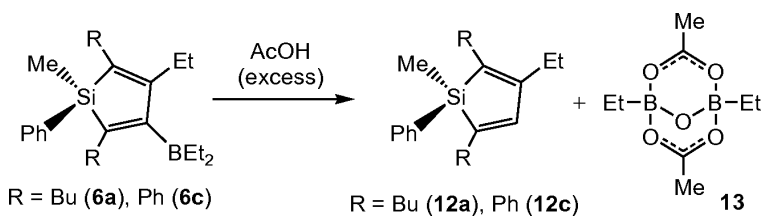

Scheme 6. Protodeborylation of two siloles using acetic acid.

the known bicyclic boron-oxygen compound 13 [21]. Interestingly, the siliole 11c does not react under the same conditions.

\section{Conclusions}

The synthesis of siloles via 1,1-organoboration of dialkyn-1-ylsilanes allows not only for variations of substituents in the positions $2-5$ but also for introducing various organyl groups to silicon, including the access to chiral siloles. Particularly noteworthy in this context are also the new spirosilanes containing silacyclobutane units.

\section{Experimental Section}

All preparative work and handling of air-sensitive chemicals were carried out by observing precautions to exclude oxygen and moisture. Dichloromethylphenylsilane, dichlorodiphenylsilane, 1,1-dichloro-silacyclobutane, 1-hexyne, 3,3-dimethyl-but-1-yne, ethynylbenzene, trimethylsilylethyne, $n$-butyllithium in hexane $(1.6 \mathrm{M})$, and triethylborane $\left(\mathrm{BEt}_{3}\right)$ were commercial products and were used without further purification. 9-Etyl-9-borabicyclo[3.3.1]nonane, Et-9-BBN, was prepared according to the literature procedure [22]. The dialkyn-1-ylsilanes $\mathbf{2}-\mathbf{5}$ were prepared in the usual way [16], and details including NMR spectrosciopic data will be reported elsewhere [17]. NMR spectra: Bruker ARX $250 \mathrm{MHz}$ or Varian Inova $300 \mathrm{MHz}$ and $400 \mathrm{MHz}$ spectrometers, all equipped with multinuclear units; measurements at $23 \pm 1{ }^{\circ} \mathrm{C}$ in $5 \mathrm{~mm}$ (o. d.) tubes, using $\mathrm{C}_{6} \mathrm{D}_{6}$ solutions $(c a .10-15 \% \mathrm{v} / \mathrm{v})$, if not mentioned otherwise. Chemical shifts are given relative to $\mathrm{SiMe}_{4}\left[\delta^{1} \mathrm{H}\left(\mathrm{C}_{6} \mathrm{D}_{5} \mathrm{H}\right)=7.15\right.$, $\delta^{13} \mathrm{C}\left(\mathrm{C}_{6} \mathrm{D}_{6}\right)=128.0, \delta^{29} \mathrm{Si}=0$ for $\mathrm{SiMe}_{4}$ with $\Xi\left({ }^{29} \mathrm{Si}\right)=$ $19.867187 \mathrm{MHz}$, and $\delta^{11} \mathrm{~B}=0$ for $\mathrm{BF}_{3}-\mathrm{OEt}_{2}$ with $\Xi\left({ }^{11} \mathrm{~B}\right)=$ $32.083971 \mathrm{MHz} .{ }^{29} \mathrm{Si}$ NMR spectra were recorded using the refocused INEPT pulse sequence with ${ }^{1} \mathrm{H}$ decoupling [23], based on ${ }^{2 / 3} J\left({ }^{29} \mathrm{Si},{ }^{1} \mathrm{H}\right) \approx 7-10 \mathrm{~Hz}$ (after optimization of the respective refocusing delays).

Reaction of dialkyn-1-ylsilanes 2-5 with triethylborane (typical procedure)

A Schlenk tube was charged with the dialkyn-1-ylsilane 2a $(0.5 \mathrm{~g} ; 1.77 \mathrm{mmol})$ where an excess of $\mathrm{BEt}_{3}(4 \mathrm{~mL})$ served as reagent as well as solvent. The reaction mixture was heated at $100-110{ }^{\circ} \mathrm{C}$ (oil bath temperature), and the progress of the reaction was monitored by ${ }^{29} \mathrm{Si}$ NMR spectroscopy. After $3 \mathrm{~d}$, when the reaction was complete, all readily volatile materials were removed in vacuo, and the oily yellowish residue was identified as the pure $(>97 \%$ according to ${ }^{1} \mathrm{H}$ NMR) silole 6a. Except for the reaction time, the experimental procedure was identical for all other members of the series, $\mathbf{6 c}(10 \mathrm{~d}), \mathbf{7 a}(23 \mathrm{~d}), \mathbf{8 a}(10 \mathrm{~h}), \mathbf{8 b}(7 \mathrm{~d}), \mathbf{8 c}$ (11 d), and $8 \mathbf{d}(6 \mathrm{~h})$. Siloles $\mathbf{8 b}$ and $\mathbf{8 c}$ were accompanied by alkenyl(alkyn-1-yl)silanes $\mathbf{1 0 b}$ and 10c for which the loss in stereoselectivity does not allow for further rearrangement.

6a: ${ }^{1} \mathrm{H}$ NMR (400 MHz): $\delta=0.5\left(\mathrm{~s}, 3 \mathrm{H},{ }^{2} J\left({ }^{29} \mathrm{Si},{ }^{1} \mathrm{H}\right)=6.5\right.$ $\mathrm{Hz}, \mathrm{Si}-\mathrm{Me}$ ), 2.2, 1.0-0.9, 0.5, 0.5 (m, m, t, t, 18H, Bu), 1.8, 0.6 (m, t, 5H, Et), 1.8-1.9, 0.7 (m, t, 10H, $\left.\mathrm{BEt}_{2}\right), 6.9-7.4$ (m, 5H, Si-Ph).

6c: ${ }^{1} \mathrm{H}$ NMR (400 MHz): $\delta=0.6$ (s, 3H, Si-Me), 2.4, 0.9 (m, t, 5H, Et), 1.5, 1.1 (m, t, 10H, BEt 2$), 7.3-7.7(\mathrm{~m}, 15 \mathrm{H}$, $\mathrm{Si}-\mathrm{Ph}, \mathrm{Ph})$.

7a: ${ }^{1} \mathrm{H}$ NMR (400 MHz): $\delta=2.1-1.9,1.3,0.9,0.5,0.4$ (m, m, m, t, t, 18H, Bu), 2.2, 0.8 (m, t, 5H, Et), 1.1, 0.9 (m, t, $\left.10 \mathrm{H}, \mathrm{BEt}_{2}\right), 6.9-7.7\left(\mathrm{~m}, 10 \mathrm{H}, \mathrm{SiPh}_{2}\right)$.

8a: Yield $=98 \% .-{ }^{1} \mathrm{H}$ NMR $(250 \mathrm{MHz}): \delta=0.9,2.0(\mathrm{t}$, q, 5H, Et), 1.0, 1.4 (t-br, q-br, 10H, $\mathrm{BEt}_{2}$ ), 0.9, 1.3-1.5, 2.2 $(\mathrm{t}, \mathrm{m}, \mathrm{t}, 18 \mathrm{H}, \mathrm{Bu}), 1.6,2.4$ (t, quint, $\left.6 \mathrm{H},\left(\mathrm{CH}_{2}\right)_{3}\right)$.

8b: ${ }^{1} \mathrm{H}$ NMR $(250 \mathrm{MHz})$ data: $\delta=0.9,2.1(\mathrm{t}, \mathrm{q}, 5 \mathrm{H}$, Et), 1.1, 1.35-1.45 (t-br, m-br, 10H, BEt 2 ), 1.2, 1.3 (s, $18 \mathrm{H},{ }^{t} \mathrm{Bu}$ ), 1.7, 2.5 (dt, quint., $6 \mathrm{H}, J\left({ }^{1} \mathrm{H},{ }^{1} \mathrm{H}\right)=2.3,8.5 \mathrm{~Hz}$, $\left.\left(\mathrm{CH}_{2}\right)_{3}\right)$.

8c: ${ }^{1} \mathrm{H}$ NMR $(250 \mathrm{MHz}): \delta=1.0,1.5$ (t-br, q-br, $10 \mathrm{H}$, $\mathrm{BEt}_{2}$ ), 1.2, 2.3 (t, q, 5H, Et), 1.5, 2.1 (t, quint., $\left.6 \mathrm{H},\left(\mathrm{CH}_{2}\right)_{3}\right)$, $7.2-7.3,7.3-7.5(\mathrm{~m}, \mathrm{~m}, 10 \mathrm{H}, \mathrm{Ph})$.

8d: Yield $=98 \% .-{ }^{1} \mathrm{H}$ NMR $(250 \mathrm{MHz}): \delta=0.2,0.3$ (s, s, 18H, $\mathrm{SiMe}_{3}$ ), 1.0, 2.2 (t, q, 5H, Et), 1.0, 1.4 (t-br, q-br, $\left.10 \mathrm{H}, \mathrm{BEt}_{2}\right), 1.6,2.5$ (t, quint., $\left.6 \mathrm{H},\left(\mathrm{CH}_{2}\right)_{3}\right)$.

9: ${ }^{1} \mathrm{H}$ NMR (400 MHz): $\delta=0.2\left(\mathrm{~s}, 9 \mathrm{H}, \mathrm{SiMe}_{3}\right), 0.2$ (s, $6 \mathrm{H}, \mathrm{SiMe}_{2}$ ), 0.9, 2.4 (t, q, 5H, Et), 1.0, 1.3 (t, q, 10H, BEt 2 ), $5.9\left(\mathrm{~s}, 1 \mathrm{H},{ }^{2} J\left({ }^{29} \mathrm{Si},{ }^{1} \mathrm{H}\right)=15.0 \mathrm{~Hz}, \mathrm{C}^{5} \mathrm{H}\right)$.

9': ${ }^{1} \mathrm{H}$ NMR $(400 \mathrm{MHz}): \delta=5.8\left(\mathrm{t}, 1 \mathrm{H},{ }^{2} J\left({ }^{29} \mathrm{Si},{ }^{1} \mathrm{H}\right)=\right.$ $\left.15.3 \mathrm{~Hz},{ }^{4} J\left({ }^{1} \mathrm{H},{ }^{1} \mathrm{H}\right)=1.9 \mathrm{~Hz}, \mathrm{C}^{5} \mathrm{H}\right) ;{ }^{29} \mathrm{Si} \mathrm{NMR}(59.6 \mathrm{MHz})$ : $\delta=-11.3,+15.4 \mathrm{ppm}$.

10b: ${ }^{1} \mathrm{H}$ NMR $(250 \mathrm{MHz}): \delta=1.1\left(\mathrm{~s}, 9 \mathrm{H},{ }^{t} \mathrm{Bu}\right), 1.4$ (s, 9H, $\left.{ }^{t} \mathrm{Bu}\right) .-{ }^{13} \mathrm{C} \mathrm{NMR}(62.8 \mathrm{MHz}): \delta=82.8$ (三C), $116.3(\mathrm{Si}-\mathrm{C} \equiv), 140.6(=\mathrm{C}), 168.4(\mathrm{br},(\mathrm{B}) \mathrm{C}=), 9.8,22.4^{\mathrm{br}}$ $\left(\mathrm{BEt}_{2}\right), 13.4,14.2,21.1\left(\mathrm{Si}\left(\mathrm{CH}_{2}\right)_{3}\right), 31.0\left({ }^{t} \mathrm{Bu}\right) .-{ }^{29} \mathrm{Si} \mathrm{NMR}$ (49.7 MHz): $\delta=-12.9$.

10c: ${ }^{1} \mathrm{H}$ NMR (250 MHz): $\delta=1.0,1.3\left(\mathrm{t}, \mathrm{q}, 10 \mathrm{H}, \mathrm{BEt}_{2}\right)$, $1.1,2.0-2.5(\mathrm{t}, \mathrm{m}, 5 \mathrm{H}, \mathrm{Et}), 1.5,2.0-2.5\left(\mathrm{t}, \mathrm{m}, 6 \mathrm{H},\left(\mathrm{CH}_{2}\right)_{3}\right)$, $7.1-7.5(\mathrm{~m}, 10 \mathrm{H}, \mathrm{Ph}) .-{ }^{13} \mathrm{C}$ NMR $(62.8 \mathrm{MHz}): \delta=87.4$ $(\equiv \mathrm{C}), 106.7(\mathrm{Si}-\mathrm{C} \equiv), 136.4(=\mathrm{C}), 165.4^{\mathrm{br}}((\mathrm{B}) \mathrm{C}=), 14.0$, $26.4(\mathrm{Et}), 9.1,22.0^{\mathrm{br}}\left(\mathrm{BEt}_{2}\right), 13.7,14.4,18.2\left(\mathrm{Si}\left(\mathrm{CH}_{2}\right)_{3}\right)$. ${ }^{29} \mathrm{Si}$ NMR (49.7 MHz): $\delta=-9.8$. 
Reaction of di(alkyn-1-yl)dimethylsilane 1c with 9-ethyl-9borabicyclo[3.3.1]nonane, Et-9-BBN

A few crystals $(0.20 \mathrm{~g} ; 0.77 \mathrm{mmol})$ of the silane 1c dissolved in $\mathrm{C}_{6} \mathrm{D}_{6}(c a .0 .5 \mathrm{~mL})$ and Et-9-BBN $(0.5 \mathrm{~mL}$, in excess) were given into an NMR tube which was sealed under argon. The reaction mixture was heated to $102 \pm 5{ }^{\circ} \mathrm{C}$ (oil bath temperature), and changes were monitored by ${ }^{29} \mathrm{Si}$ NMR spectroscopy (Fig. 3). After $7 \mathrm{~d}$ the NMR tube was cooled in liquid $\mathrm{N}_{2}$ and opened carefully. The contents of the tube were dissolved in pentane $(5 \mathrm{~mL})$. After removing all volatiles including the excess of Et-9-BBN (b. p. $=40-$ $42{ }^{\circ} \mathrm{C} / 0.9$ Torr) in vacuo, the pure silole (>97\% according to ${ }^{1} \mathrm{H}$ NMR) 11c was obtained as a waxy solid.

11c: ${ }^{1} \mathrm{H}$ NMR $(400 \mathrm{MHz}): \delta=0.2\left(\mathrm{~s}, 6 \mathrm{H}, \mathrm{SiMe}_{2}\right), 0.8$, 1.1, 1.5, 1.7-1.8, 2.0, 2.1, 3.2 (t, b, m, m, m, m, m, 19H, B-Et, $\left.\mathrm{BC}_{8} \mathrm{H}_{14}\right), 6.8-7.1,7.2,7.3$ (m, m, m, 10H, Ph).

\section{Protodeborylation of siloles $\mathbf{6} \boldsymbol{a}$ and $\mathbf{6 c}$ (typical procedure)}

The silole 6a $(1.0 \mathrm{~g})$ was dissolved in pentane $(10 \mathrm{~mL})$, and glacial acetic acid (1.0 mL, in excess) was slowly added. The reaction mixture was stirred at r.t. After 40 min all readily volatile materials were removed under reduced pressure. The oily residue was identified as a mixture of the silole 12a and the bicyclic boron-oxygen compound $13\left({ }^{1} \mathrm{H},{ }^{11} \mathrm{~B},{ }^{13} \mathrm{C}\right.$ and $\left.{ }^{29} \mathrm{Si} \mathrm{NMR}\right)$. The mixture was heated to $100{ }^{\circ} \mathrm{C}$ under vacuum ( $c a .10^{-2}$ Torr) for $1 \mathrm{~h}$, adopting the literature procedure [24] for separation of the boron-oxygen product 13. The boron-oxygen compound was collected as a solid along the walls of the Schlenk tube. The oily residue contained mainly the desired protodeborylated silole 12a ( $>95 \%$; Fig. 1). The identical experimental procedure was adopted for protodeborylation of 12c. The silole derivatives $12 \mathrm{a}$ and $\mathbf{1 2 c}$ are colorless oily liquids, stable in dry air, and they were fully characterized by multinuclear NMR spectroscopy (Table 3 ).

12a: ${ }^{1} \mathrm{H}$ NMR $(400 \mathrm{MHz}): \delta=0.5\left(\mathrm{~s}, 3 \mathrm{H},{ }^{2} J\left({ }^{29} \mathrm{Si},{ }^{1} \mathrm{H}\right)=\right.$ $6.5 \mathrm{~Hz}, \mathrm{Si}-\mathrm{Me}$ ), 1.1, 2.2 (t, q, 5H, Et), 0.7, 0.8, 1.1, 1.3, 2.3 $(\mathrm{t}, \mathrm{t}, \mathrm{m}, \mathrm{m}, \mathrm{t}, 18 \mathrm{H}, \mathrm{Bu}), 6.5\left(\mathrm{~s}, 1 \mathrm{H},{ }^{3} J\left({ }^{29} \mathrm{Si},{ }^{1} \mathrm{H}\right)=13.4 \mathrm{~Hz}\right.$, $\left.\mathrm{C}^{4} \mathrm{H}\right), 7.5,7.1(\mathrm{~m}, \mathrm{~m}, 5 \mathrm{H}, \mathrm{Si}-\mathrm{Ph})$.

12c: ${ }^{1} \mathrm{H}$ NMR $(400 \mathrm{MHz}): \delta=0.6\left(\mathrm{~s}, 3 \mathrm{H},{ }^{2} J\left({ }^{29} \mathrm{Si},{ }^{1} \mathrm{H}\right)=\right.$ $6.6 \mathrm{~Hz}, \mathrm{Si}-\mathrm{Me}$ ), 1.0, 2.4 (t, q, 5H, Et), 6.9-7.1, 7.4, 7.6, $7.9(\mathrm{~m}, \mathrm{~m}, \mathrm{~m}, \mathrm{~m}, 15 \mathrm{H}, \mathrm{Si}-\mathrm{Ph}, \mathrm{Ph}), 7.3\left(\mathrm{~s}, 1 \mathrm{H},{ }^{3} J\left({ }^{29} \mathrm{Si},{ }^{1} \mathrm{H}\right)=\right.$ $\left.13.1 \mathrm{~Hz}, \mathrm{C}^{4} \mathrm{H}\right)$.

\section{Acknowledgements}

This work was supported by the Deutsche Forschungsgemeinschaft. E. K. is grateful to DAAD and HEC (Pakistan) for a scholarship.
[1] a) T. Hiyama, A. Mori, Science of Synthesis 2002, 4, 647; b) G. Deleris, J. Dunogues, R. Calas, P. Lapouyade, J. Organomet. Chem. 1974, 80, C45; c) C. Ackerhans, H.W. Roesky, D. Vidovic, J. Magull, Eur. J. Inorg. Chem. 2003, 66; d) H. Sugita, Y. Hatanaka, T. Hiyama, Chem. Lett. 1996, 379; e) D. Mesnard, L. Miginiac, J. Organomet. Chem. 1991, 420, 163; f) C. Mechtler, M. Zirngast, J. Baumgartner, C. Marschner, Eur. J. Inorg. Chem. 2004, 3254; g) H. Jiang, S. Zhu, Tetrahedron Lett. 2005, 46, 517; h) C. Rüdinger, H. Beruda, H. Schmidbaur, Z. Naturforsch. 1994, 49b, 1348.

[2] a) K. Uchida, K. Utimoto, H. Nozaki, Tetrahedron 1977, 33, 2987; b) J. A. Soderquist, B. Santiago, Tetrahedron Lett. 1990, 31, 5113; c) R. Yamaguchi, H. Kawasaki, T. Yoshitome, M. Kawanisi, Chem. Lett. 1982, 1485; d) G. A. Molander, J. Org. Chem. 1983, 48, 5409; e) H. Lang, K. Köhler, M. Büchner, Chem. Ber. 1995, 128, 525; f) H. Lang, M. Weinmann, L. Zsolnai, J. Organomet. Chem. 1996, 522, 277; g) H. Lang, U. Lay, M. Weinmann, J. Organomet. Chem. 1992, 436, 265.

[3] a) T. Takahashi, Z. Xi, Y. Obora, N. Suzuki, J. Am. Chem. Soc. 1995, 117, 2665; b) H. Ito, K. Arimoto, H. Sensui, A. Hosomi, Tetrahedron Lett. 1997, 38, 3977; c) T. Yu, X. Sun, C. Wang, L. Deng, Z. Xi, Chem. Eur. J. 2005, 11, 1895; d) Z. Xi, R. Fischer,
R. Hara, W.-H. Sun, Y. Obora, N. Suzuki, K. Nakajima, J. Am. Chem. Soc. 1997, 119, 12842; e) J. Liu, S. Zhang, W.-X. Zhang, Z. Xi, Organometallics 2009, 28, 413; f) M. Zirngast, C. Marschner, J. Baumgartner, Organometallics 2006, 25, 4897.

[4] M. Zaidlewicz, M. Krzeminski, Science of Synthesis 2004, 6, 1097.

[5] a) A. Pelter, K. Smith, H. C. Brown, Borane Reagents, Academic Press, London, 1988; b) K. Hirano, H. Yorimitsu, K. Oshima, Chem. Commun. 2008, 3234; c) T. C. M. Chung, Polymer News 2003, 28, 238.

[6] H. C. Brown, Organic Syntheses via Boranes, WileyInterscience, New York, 1975.

[7] B. Wrackmeyer, O. L. Tok, Comprehensive Heterocyclic Chemistry III, (Eds.: A. R. Katritzky, C. A. Ramsden, E. F. V. Scriven, R. J. K. Taylor), Elsevier, Oxford, 2008, Chapter 3.17, pp. 1181; and refs. therein.

[8] M. Saito, M. Yoshioka, Coord. Chem. Rev. 2005, 249, 765 .

[9] a) J. Dubac, A. Laporterie, G. Manuel, Chem. Rev. 1990, 90, 215; b) E. Colomer, R. J.P. Corriu, M. Lheureux, Chem. Rev. 1990, 90, 265; c) D. A. Armitage, in Comprehensive Heterocyclic Chemistry II, Vol. 2 (Ed.: C.W. Bird), Elsevier, Oxford, 1996, pp. 903; d) J. Dubac, C. Guerin, O. Meunier, in Chemistry of Organic Silicon Compounds, Vol. 2, (Eds.: Z. Rappoport, Y. Apeloig), Wiley, Chichester 1998, 
pp. 1961; e) Y. Pa, in Silicon Compounds: Silanes and Silicones, (Eds.: B. Arkles, G. Larson), Gelest Inc., Morrisville PA, 2004, p. 73.

[10] a) R. Köster, G. Seidel, J. Süß, B. Wrackmeyer, Chem. Ber. 1993, 126, 1107; b) B. Wrackmeyer, G. Kehr, J. Süß, Chem. Ber. 1993, 126, 2221.

[11] a) B. Wrackmeyer, Coord. Chem. Rev. 1995, 145, 125; b) B. Wrackmeyer, Heteroatom Chem. 2006, 17, 188, and refs. therein.

[12] G. Dierker, J. Ugolotti, G. Kehr, R. Fröhlich, G. Erker, Adv. Synth. Catal. 2009, 351, 1080.

[13] C. Booker, X. Wang, S. Haroun, J. Zhou, M. Jennings, B. L. Pagenkopf, Z. Ding, Angew. Chem. 2008, 120, 7845; Angew. Chem. Int. Ed. 2008, 47, 7731.

[14] a) N. Yu, C. Wang, F. Zhao, L. Liu, W.-X. Zhang, Z. Xi, Chem. Eur. J. 2008, 14, 5670; b) X. Zhan, A. Haldi, C. Risko, C. K. Chan, W. Zhao, T. V. Timofeeva, A. Korlyukov, M. Yu. Antipin, S. Montgomery, E. Thompson, Z. An, B. Domercq, S. Barlow, A. Kahn, B. Kippelen, J.-L. Bredas, S. R. Marder, J. Mat. Chem. 2008, 18, 3157; c) H.-J. Son, W.-S. Han, J.-Y. Chun, S.-N. Kwon, J. Ko, S. O. Kang, Organometallics 2008, 27, 2464; d) L. Heng, J. Zhai, A. Qin, Y. Zhang, Y. Dong, B.Z. Tang, L. Jiang, ChemPhysChem 2007, 8, 1513; e) P. M. DiCarmine, X. Wang, B. L. Pagenkopf, O. A. Semenikhin, Electrochem. Commun. 2008, 10, 229.

[15] a) F. Wang, L. Wang, J. Chen, Y. Cao, Macromol. Rapid Commun. 2007, 28, 2012; b) S.-C. Lo, P.L. Burn, Chem. Rev. 2007, 107, 1097; c) J. Lee, Q.-D. Liu, D.-R. Bai, Y. Kang, Y. Tao, S. Wang, Organometallics 2004, 23, 6205 .
[16] a) W. E. Davidsohn, M. C. Henry, Chem. Rev. 1967, 67, 73; b) L. Brandsma, Preparative Acetylenic Chemistry ( $2^{\text {nd }}$ ed.), Elsevier, Amsterdam, 1988; c) L. Brandsma, Synthesis of Acetylenes, Allenes, Cumulenes - Methods and Techniques, Elsevier, Amsterdam, 2004.

[17] E. Khan, B. Wrackmeyer, 2009, manuscript in preparation.

[18] B. Wrackmeyer, J. Süß, Z. Naturforsch. 2002, 57b, 741.

[19] B. Wrackmeyer, E. Khan, S. Bayer, K. Shahid, Z. Naturforsch. 2007, 62b, 1174.

[20] E. Khan, S. Bayer, B. Wrackmeyer, Z. Naturforsch. 2009, 64b, 47.

[21] B. Wrackmeyer, E. Khan, R. Kempe, Z. Naturforsch. 2008, 63b, 275.

[22] R. Köster, G. Griaznow, W. Larbig, P. Binger, Liebigs Ann. Chem. 1964, 672, 1.

[23] a) G. A. Morris, R. Freeman, J. Am. Chem. Soc. 1979, 101, 760; b) G. A. Morris, J. Am. Chem. Soc. 1980, 102, 428; c) G. A. Morris, J. Magn. Reson. 1980, 41, 185 ; d) D. P. Burum, R. R. Ernst, J. Magn. Reson. 1980, $39,163$.

[24] a) E. Khan, B. Wrackmeyer, R. Kempe, Eur. J. Inorg. Chem. 2008, 5367; b) E. Khan, R. Kempe, B. Wrackmeyer, Appl. Organomet. Chem. 2009, 23, 124.

[25] a) B. Wrackmeyer, Progr. NMR Spectrosc. 1979, 12, 227; b) B. Wrackmeyer, Annu. Rep. NMR Spectrosc. 1988, 20,61 . 